\title{
EFFECT OF GIBBERELLIC ACID ON SOME PHYSIOLOGICAL; REPRODUCTIVE AND HATCHABILITY PARAMETERS OF LAYING HENS DURING WINTER AND SUMMER SEASONS
}

\author{
A.A. Askar and E.I. IsmaeIl \\ Poultry Department, Faculty of Agriculture, Zagazig University, Zagazig, Egypt
}

\section{SUMMARY}

An experiment was carried out to investigate the hormonal effect of gibberellic acid (GA3) on some physiological; reproductive parameters and hatchability performance of laying hens during winter and summer seasons of Egypt. A total of 120 hens (60 per each season) at the end of the production curve (62 wks of age) were randomly divided into three equal treatment groups that bi-weekly injected

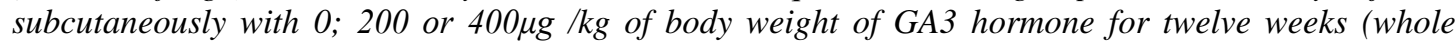
experimental period). Egg number or weight and some egg quality parameters were of nearly similar values during winter or summer seasons. Most of these traits were slightly improved due to the injection by GA3, especially egg number and shell thickness that increased significantly $(P<0.01)$ either with 400 or $200 \mu \mathrm{g}$ of GA3 comparing with those of control group hens $(21.07 ; 21.15$ and 19.09 eggs, resp. and 0.36; 0.36 and $0.34 \mathrm{~mm}$, resp.). Most of some haematological parameters were affected significantly due to season effects, except $\mathrm{Hb}$ and $\mathrm{H} / \mathrm{L}$ ratio that showed nearly similar values during the two seasons. Hens during winter season had significantly $(P<0.05$ or 0.01$)$ higher estimates of WBCs; PCV; heterocytes and lymphocytes and lower estimate of RBCs than those of hens in summer season. Values of WBCs; RBCs; PCV and lymphocytes were improved significantly $(P<0.05$ or 0.01$)$ in hens injected by GA3, especially with the level of $400 \mu \mathrm{g}$ that caused a better improvement than that of the other one $(200 \mu \mathrm{g})$. Values of $\mathrm{Hb}$; heterocytes and $\mathrm{H} / \mathrm{L}$ ratio didn't differ significantly due to GA3 effects, however, $\mathrm{Hb}$ and heterocytes estimates tended to improve in hens treated with GA3. Hens in winter season recorded significantly $(P<0.05$ or 0.01$)$ higher values of total protein; globulin and total lipids and lower value of glucose than those of hens in summer season. Also, albumin value was increased in winter season, but not significantly. GA3 increased all values of the blood components (total protein; albumin; globulin; glucose and total lipids). However, the increasing was significant $(P<0.01)$ only in total protein and albumin $(4.78$ and $2.57 \mathrm{~g} / \mathrm{dl}$, resp. $)$ in hens injected by $400 \mu \mathrm{g}$ of GA3 compared with either those injected by $200 \mu \mathrm{g}(4.44$ and $2.24 \mathrm{~g} / \mathrm{dl}$, resp.) or control group (4.24 and $2.14 \mathrm{~g} / \mathrm{dl}$, resp.). Fertility and hatchability of total egg set or of fertile eggs percentages did not show any significant deference due to season effects, however, winter season had slightly higher values of these parameters than those of summer ones. On the other hand, chick weight or chick weight percentage were significantly higher $(P<0.05)$ in winter season than those of summer ones $(38.54$ and $65.67 \mathrm{vs.} 37.71$ and 64.70, resp.). Hatchability of total egg set or of fertile eggs percentages and chick weight or chick weight percentage were tended to be slightly higher for hens injected with $400 \mu \mathrm{g}$ of GA3 than those of hens injected with $200 \mu \mathrm{g}$ or those of control group ones. Fertility percentage was

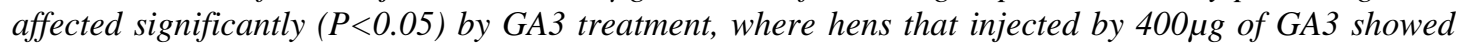
the highest value (86.67\%) with $29 \%$ more than that of control group (66.67\%). Interaction effects between season and GA3 on studied traits were insignificant. In conclusion, most of haematobiochemical traits of blood and chick weight were improved during winter seasons. In addition, GA3 has a positive effect on productive performance and fertility of laying hens.

Keywords: Gibberellic acid, egg quality, blood components, fertility, hatchability, laying hens

\section{INTRODUCTION}

Gibberellic acid (actually a group of related substances called gibberellins) was discovered as a metabolic byproduct of the fungus Gibberella fujikuroi (Riley, 1987). Gibberellic acid (GA3) has many effects regulating various physiological processes including seed germination, the mobilization of endosperm storage reserves, shoot growth, cell elongation, in flowering and parthenocarpic fruit development and in the mobilization of food reserves in grass, in seed germination and in juvenility and sex expression (Seetharim and Ksuma-Kumari, 1975; Aswathanrayana and Mahadevappa, 1977 and Salisbury and Ross, 1992). Moreover, El-Mofty and Sakr (1988) reported that GA3 is a plant growth regulator used in many countries, including Egypt, to increase the growth of fruits and vegetables.

Because of the possible use of Gibberellins in plant growth, regulators gave entry into animal cells through diet. GA3 is an extensively prevalent plant growth regulator 
due to its use in agriculture by spray applications for promoting plant growth in field crops and the presence of potentially high residual levels on plant materials, which can be used in poultry feeds. Recent research has indicated that Plant growth regulators expressed biological potentials in animal cells. Alkhiat et al. (1981), Madacsi et al. (1988) and Abd-Elhamid et al. (1994) reported positive influences of GA3 on body weights and fecundity of rats, poultry, pigs and calves, as well as, an increase in circulating WBCs, hematocrit value and thymus weight in young deer mice (De Man et al., 1991). Anderson et al. (1982) studied the effect of injecting 72weeks old brown egg type hens with $400 \mu \mathrm{g}$ of GA3 for 6 alternate days. They reported a significantly greater mean of egg production that accompanied by $23 \%$ less feed consumed per egg and a progressive increase in egg numbers and weight with time until the $3^{\text {ed }}$ week post injection then, it was slightly decreased thereafter. Meanwhile, shell thickness dropped in birds injected by $6 \%$ of GA3 at the end of 1 st week, and then it was fluctuated with time.

Abd-Elhamid et al. (1994) reported that feeding two-weeks-old broiler chicks on diets containing GA3 at $0,1,5,25$, and $125 \mathrm{ppm}$ levels respectively for 3 weeks lowered the percentage of glands (adrenal, thyroid and pituitary) weights comparing with the control. Blood protein raised significantly, whereas, blood glucose increased but not significantly. These positive influences of GA3 might be related to the changes in the levels of circulating gonadal hormones, since GA3 has been shown to have estrogenic activity in hens (Anderson et al., 1982). In addition, GA3 treatment increased the weight of uterus and ovaries, since it may act synergistically with exogenous or endogenous estrogen and produced an enhanced growth of uterine tissue (Gawienowski et al., 1977 and Alkhiat et al., 1981). Results of Gawienowski and Chatterjee (1980) indicated that GA3 activity in mammalian species might act via the prostaglandin or/and estrogens through the bioassay in ovaricetomized mouse.

Therefore, the present study aimed to investigate the effect of GA3 on some physiological parameters and hatchability performances of laying hens during winter and summer seasons of Egypt at the end of the production curve.

\section{MATERIALS AND METHODS}

The present study was carried out at the Agricultural Co-operation Farm in Sharkiya Governorate, Egypt, during winter and summer of $2009 / 2010$ to determine the effect of
Gibberellic acid (GA3) subcutaneously injected as a plant hormone on some physiological parameters; reproductive and hatchability performance of Hi-line laying hens.

GA3 hormones in powder form is easily soluble in methanol, ethanol, acetone and insoluble in water. GA3 is purchased from ElGomhoriaa Company for Chemicals, Sharkiya Governorate, Egypt. Hormone was dissolved in ethanol after that mixed with sesame oil and buffered solution for subcutaneously weekly injection (under neck skin bird) with $0.2 \mathrm{ml}$ buffer solution containing different concentrations of GA3 per $\mathrm{kg}$ of body weight (200 and $400 \mu \mathrm{g})$. Hormone was dissolved in sesame oil mixture $(1: 11)$ with $2 \mathrm{mg} \mathrm{NaHCO}_{3}$ per $0.2 \mathrm{ml}$ of buffered solution for injection.

One hundred and twenty Hi-line laying hens (60 per each season) at the end of the production curve (62 wks of age) were randomly divided into three equal treatment groups (20 birds each) with five replicates (4 birds each). Birds were maintained in layer cages $(40 \times 40 \times 38 \mathrm{~cm})$ of four birds in each with 16 hours light per day through the experimental period. Birds in all treatments were nearly similar in the average initial body weight. All birds were kept under the same managerial conditions. Birds were fed adlibitum and fresh water was available during the experimental period. Birds were fed the experimental diet $(17 \%$ Crude protein; 2750 kcal ME / kg diet; $3.3 \%$ Crude fat; $3 \%$ Crude fiber; $4 \% \mathrm{Ca}$ and $0.45 \%$ available $\mathrm{P}$ ) that met all nutritional requirements of laying hens according to NRC (1994). Calcium level of the diet was recommended for laying hens at the end of the production curve (Ahmad et al., 2003; Narvaez-Solarte et al., 2006 and Pelicia et al., 2009). Ambient temperature and relative humidity were recorded in house of birds at the middle of the day. Minimum and maximum indoor ambient temperature and relative humidity during winter and summer season of this trial ranged from $15-26$ and $29-35{ }^{\circ} \mathrm{C} \&$ 30-45 and 50-65\%, respectively (averaged 18 and $31{ }^{\circ} \mathrm{C} \& 41$ and $56 \%$, resp.). The $2^{\text {nd }}$ and $3^{\text {rd }}$ Group of birds were bi-weekly injected subcutaneously with $0.2 \mathrm{ml}$ per $\mathrm{kg}$ of body weight of GA3 hormone dissolved in ethanolsesame oil solution mixture $(1: 11)$ which contained 200 or $400 \mu \mathrm{g}$ per $\mathrm{kg}$ of body weight, respectively for twelve weeks (whole experimental period). Each $0.2 \mathrm{ml}$ of this solution contained $2 \mathrm{mg}$ of $\mathrm{NaHCO}_{3}$. The first group served as a control group and treated in a like manner with the ethanol-sesame oil mixture only. Artificial insemination technique was adopted for mating hens to attain fertile eggs for estimating the hatchability performance during the experimental period. 
Semen was collected from chosen and trained cocks for hens insemination two times per week.

Egg number and weight was recorded daily through the experimental period. Egg quality (egg yolk and albumen ratios as a percentage of egg weight and shell thickness) was measured at the end of the treatment period. Blood samples were withdrawn from the brachial vein, five hens chosen randomly from every treatment group. Heparin was used as an anticoagulant to determine blood haematology but a part of samples was held to obtain serum to measure blood components. Serum was obtained by blood centrifugation at $3000 \mathrm{rpm}$ for 20 minutes and stored at $-20 \mathrm{C}^{\mathrm{O}}$ until analysis. Haemoglobin $(\mathrm{Hb})$ concentration (g/dl) was estimated by cyanomethemoglobin method according to Eilers (1967). Wintrobe haematocrit tubes were used for determination the packed cell volume (PCV) as a percentage. Red blood cell's (RBCs) counts were counted on AO Bright line haemocytometer using a light microscope at 400x magnification after diluting blood samples 200 times with a physiological saline $(0.9 \% \mathrm{NaCl}$ solution $)$ before counting. WBC's count was measured according to Winterobe (1967). Heterophils and lymphocytes percentages were counted in different microscopic fields in a total of 200 WBCs by the same person. Plasma total protein concentration $(\mathrm{g} / \mathrm{dl})$ was measured by the Biuret method as described by Armstrong and Carr (1964). Albumin concentration (g/dl) was determined colorimetrically according to Wise (1965). Globulin concentration (g/dl) was calculated by subtraction of albumin content from the total proteins content. Total lipids (TL) concentration (mg/dl) was estimated colorimetrically according to the method described by Schmit (1964).

Data were statistically analyzed using GLM in SPSS programme (1993) according to the following model: $Y_{i j k}=\mu+S_{i}+G_{j}+S_{i j}+$ $\mathrm{e}_{\mathrm{ijk}}$

Where, $Y_{\mathrm{ijk}}=$ an observation; $\mu=$ general mean; $S_{i}=$ fixed effect of $i^{\text {th }}$ season, $i=1 \& 2$ (winter or summer); $G_{j}=$ fixed effect of $j^{\text {th }}$ GA3 level, $\mathrm{i}=1 ; 2$ and $3(0.0 ; 200$ or $400 \mu \mathrm{g}$ per $\mathrm{kg}$ of body weight); $\mathrm{SG}_{\mathrm{ij}}=$ interaction effect of $i^{\text {th }}$ season and $j^{\text {th }}$ GA3 level and $e_{i j k}=$ error of the model, which included all the other effects not specified in the mixed model. Differences among experimental groups were separated by Duncan's multiple range test (Duncan, 1955).

\section{RESULTS AND DISCUSSION}

Egg number or weight and some egg quality presented in Table 1 were of nearly similar values during winter or summer seasons. However, most of these traits were slightly improved due to the injection by GA3, especially egg number and shell thickness that significantly increased $(\mathrm{P}<0.01)$ either with 400 or $200 \mu \mathrm{g}$ of GA3 comparing with those of control group hens $(21.07 ; 21.15$ and 19.09 eggs, resp. and $0.36 ; 0.36$ and $0.34 \mathrm{~mm}$, resp.). Most of literature reviewed showed that egg production and quality were decreased in hot conditions (Muiruri and Harrison, 1991; Mahmoud et al., 1996; Bollengier-Lee et al., 1999; De-Fariara et al., 2001; Kirunda et al., 2001 and Mashaly et al., 2004). However, it must be kept in mind that when hens are towards the end of their reproductive period, they lose many of their feathers beside the presence of some chemical or metabolic mechanisms, such as changing the amount of feed consumed or the activity of some endocrine glands (hypophysis, thyroid, adrenals and pancreas), therefore they have a high ability to alleviate the effect of hot condition (Meltzer, 1987).

The present results are in agreement with those of Anderson et al. (1982) who found that GA3 significantly increased egg production and Elkomy et al. (2008) and Ismail (2009) who showed a significant improvement in egg production of Gemiza hens that treated by GA3 where the moderate dose of GA3 (200 $\mu \mathrm{g})$ had the highest mean of egg production. This increase in egg production might be due to that GA3 treated group had higher circulating estrogenic hormone and the metabolic activity of GA3 enhanced ovulatory process (Anderson et al., 1982). As well as, Khalifa et al. (1983) concluded that; the improvement in egg production by estradiol can be explained by the physiological effect of estrogen upon the ovary and oviduct which causing their activation and enhancing ovulatory process. Also, Hamdy et al. (2002) reported that, egg mass was significantly and positively correlated with plasma concentration of estrogen. Similar to the present findings, Khalifa at al. (1983) found that, egg weight increased with estradiol treatment over control but not significantly. Also, Elkomy et al. (2008) reported no significant effect for GA3 treatment on egg weight of Gemiza hens. On the other hand, Anderson et al. (1982) observed a significant increase in egg weight in GA3 treated group of 72 weeks old brown type hens. Concerning eggshell traits, agreement observations were obtained by Elkomy et al. (2008) who said that eggshell thickness was gradually increased in treated 
hens by GA3. Furthermore, the birds treated with $400 \mu \mathrm{g}$ GA3 had the highest $(\mathrm{P}<0.05)$ eggshell thickness value, while albumin; yolk and eggshell weight percentages indicated no significant increase due to GA3 treatments hens. This author showed that the increase in eggshell thickness followed the increase in serum calcium levels and may be due to enhancing calcium transport in eggshell gland. In the same line, a good correlation was observed between estradiol administration and eggshell quality of hens (Grunder et al., 1983). El-Afifi and Abou Taleb (2002) reported that eggshell weight and thickness was significantly improved in old egg-laying Japanese quail fed a diet supplemented with 9 $\mathrm{mg} / \mathrm{kg}$ diet of estradiol benzoat.

Most of haematological parameters presented in Table 2 were affected significantly due to season effects, except $\mathrm{Hb}$ and $\mathrm{H} / \mathrm{L}$ ratio that showed nearly similar values during the two seasons. Hens during winter season had significantly $(\mathrm{P}<0.05$ or 0.01) higher estimates of WBCs; PCV; heterocytes and lymphocytes and lower estimate of RBCs than those of hens in summer season. Nearly similar observations were reported also by Oladele et al. (2003), who found significantly low levels of packed cell volume and haemoglobin values in domestic chickens during the hot-dry season. The lower values of packed cell volume recorded during the hot-dry season in the zone were attributed to heat and nutritional stress, which impair the synthesis of blood cells in birds (Oladele et al., 2001). Oladele et al. (2001) demonstrated that correlation coefficient values between ambient temperature and packed cell volume during the hot dry and rainy seasons were - 0.996 and 0.903 , respectively. In the same trend, Niu et al. (2009) said that the immune response, which includes WBCs was reduced in chicks exposed to high temperature ranged from 32$43{ }^{\circ} \mathrm{C}$. The high chance to alleviate hot condition effect on hens at the end of their reproductive period through losing many of their feathers beside the presence of some chemical or metabolic mechanisms, such as changing the amount of feed consumed or the activity of some endocrine glands (Meltzer, 1987) may be explain the nearly similar values of $\mathrm{Hb}$ and $\mathrm{H} / \mathrm{L}$ ratio during the two seasons. However, the lower estimate of RBCs in winter than those of hens in summer is not easy to explain.

Values of WBCs; RBCs; PCV and lymphocytes were improved significantly $(\mathrm{P}<0.05$ or 0.01$)$ in hens injected by GA3, especially with the level of $400 \mu \mathrm{g}$ that caused a better improvement than that of the other one $(200 \mu \mathrm{g})$. In contrast, values of $\mathrm{Hb}$; heterocytes and $\mathrm{H} / \mathrm{L}$ ratio didn't differ significantly due to GA3 effects, in spite of that $\mathrm{Hb}$ and heterocytes estimates tended to improve in hens treated with GA3 (Table 2). Similar results were obtained also by Ismail (2009) who found that Values of RBC's and Hb were significantly $(\mathrm{P}<0.01)$ increased in laying hens injected with GA3 compared with control group. In addition, in male albino rats, Muthu1 et al., (2011) found that estimates of RBCs; WBCs and neutrophil were significantly increased at all doses of GA3 treatment, possibly due to an action of GA3 on hemopoiesis, while lymphocytes were decreased. In contrast, Elkomy et al. (2008) said that GA3 doses had a significant effect on overall means of $\mathrm{Hb}$ concentration and a significant increase effect on PCV value, meanwhile red blood cell count was not significantly affected by the GA3 treatment in Gemiza hens.

Hens in winter season recorded significantly $(\mathrm{P}<0.05$ or 0.01$)$ higher values of total protein; globulin and total lipids and lower value of glucose than those of hens in summer season, meanwhile albumin value was increased also in winter season, but didn't reach to the significant level (Table 3). Confirming to these results, total protein value also had a significant and negative relationship with elevated ambient temperature, since, values obtained during the hot dry and rainy seasons were - 0.998 and 0.999 (Oladele et al., 2001), indicating that heat stress exerts adverse effects on protein synthesis. Similarly, Zhou et al. (1998) and Sahin et al. (2001) demonstrated a significant negative effect of heat stress on total proteins in broiler chickens. Serum cholesterol were considerably decreased when male broiler exposed to acute heat stress $\left(36^{\circ} \mathrm{C}\right.$ for 6 hours) at 8th week of age (Zulkifli et al., 1999).

The treatment by GA3 increased all values of the blood components presented in Table 3 (total protein; albumin; globulin; glucose and total lipids). Whoever the increasing was significant $(\mathrm{P}<0.01)$ only in total protein and albumin that reach to the highest values (4.78 and $2.57 \mathrm{~g} / \mathrm{dl}$, resp.) in hens injected by $400 \mu \mathrm{g}$ of GA3 as comparing with those injected by $200 \mu \mathrm{g}$ (4.44 and $2.24 \mathrm{~g} / \mathrm{dl}$, resp.) or those of control group (4.24 and $2.14 \mathrm{~g} / \mathrm{dl}$, resp.). Results of this work were in agreement with those obtained by Abd-Elhamid et al. (1994) who found that GA3 raised blood protein significantly when the broiler chicks were fed diets containing different levels of GA3 and those of Elkomy et al. (2008) who reported an insignificantly increase in hen's total protein due to GA3 treatments. On contrary, Elkomy et al. (2008) showed that albumin concentration of hens was not significantly 
affected by GA3 at any dose. Muthu1 et al. (2011) said that total protein and albumin content were not significantly altered by any dose of GA3, indicating that the protein metabolism was not affected by GA3 in male albino rats. Concerning to glucose concentration, this increase in plasma glucose found with GA3 in the present study is in closely agreement with those of Abd-Elhamid et al. (1994) who found that, when the broiler chicks fed diets containing GA3 at different levels, blood glucose increased but not significantly. Also, Elkomy et al. (2008) said that plasma glucose concentration was significantly higher in Gemiza hens treated with $100 \mu \mathrm{g}$ of GA3. The changes in carbohydrate metabolism induced by GA3 treatment increase the hen's blood glucose concentration, this may be correlated with the effect of GA3 on the activities of hepatic enzymes system, which are intimately involved in glucose production, storage and metabolism (Bell and Freeman 1971), since, the data of liver glycogen revealed a significant increase in liver glycogen content in the GA3 treated groups compared with the control at the end of the treatment period, and/or correlated with the endocrine activity of the pancreas, whereas, pancreatic weight was increased significantly (Elkomy et al., 2008). In contrast, Muthu1 et al. (2011) reported a progressive decrease in the quantity of glucose in male albino rats at all doses of GA3 treatment. The results of total lipids obtained in the present study are in accordance with those of Pearce and Johnson (1986) who mentioned that, blood total lipids of fowls were increased during the laying period. In addition, estrogen administration caused a similar rise in the immature fowl blood total lipids, since this effect of GA3 is similar with that of estrogen hormone. Elkomy et al. (2008) showed that no significant differences in Plasma total lipids in Gemiza hens were found due to GA3 treatment. However, plasma total lipids for hens treated with GA3 doses were higher than that of the control group. Increasing plasma total lipids concentration in the GA3 treated groups compared to the control, may be due to that GA3 activates the fat metabolism to provide yolk by lipids required for yolk formation (Elkomy et al., 2008). Whereas, the yolk lipids content was increased for the hens treated with GA3.

Fertility and hatchability of total egg set or of fertile eggs percentages did not show any significant difference due to season effects (Table 4), however winter season had slightly higher values of these parameters than those of summer one. On the other hand, chick weight (g) or chick weight percentage were significantly higher $(\mathrm{P}<0.05)$ in winter season than those of summer one (38.54 and 65.67 vs. 37.71 and 64.70, resp.). These findings supported those obtained by Dantzer and Kelly (1989), who reported that physical and emotional stressors suppress immunity through the activation of cytokine IL-1 that induces fever and reduces feed intake, as well as, stimulates the hypothalamic-pituitary-adrenal axis and inhibits the hypothalamic-pituitarygonadal functions. This observation is apparently explaining the proximate mechanism of heat-induced infertility in domestic animals, including the domestic chicken. According to these observations of Dantzer and Kelly (1989), it is reasonable to conclude that high environmental temperatures stress disturbs the pulsatile gonadotrophin releasing hormone generator frequency, which in turn compromises reproductive functions axis as a result to the impairment in secretion of follicle-stimulating and luteinising hormones in laying birds due to heat-stress.

Commercial or scientific hatchability percentages and chick weight (g) or chick weight percentage were slightly higher for hens injected with $400 \mu \mathrm{g}$ of GA3 than those of hens injected with $200 \mu \mathrm{g}$ or those of control group ones (Table 4). Fertility percentage significantly affected $(\mathrm{P}<0.05)$ due to GA3 treatment, where hens injected by $400 \mu \mathrm{g}$ of GA3 showed the highest value $(86.67 \%)$ with an increase of $29.9 \%$ than that of control group $(66.67 \%)$. Similar observations were reported in Japanese quail female birds by ElSebai et al. (2003), who showed that GA3 treatment had a little and insignificant effect on fertility percentage, while hatchability ene was significantly $(\mathrm{P}<0.05)$ improved due to GA3 treatment. The improvement in fertility; hatchability and chick traits my be attributed to the beneficial effects of GA3 on egg quality, since part of the metabolic activity in birds is inducing an increase in estrogen levels and/or produce direct estrogen-like action (Gawienwski and Chatterijee, 1980).

The effects of interaction between season and GA3 treatment were insignificant for all studied parameters in the present work.

\section{CONCLUSION}

From these results, it can be concluded that most of haematobiochemical traits and chick weight were improved during winter seasons. In addition, GA3 has a positive effect on productive performance and fertility of laying hens.

\section{REFERENCES}

Abd-Elhamid, A.M., T.M Dorra, M.A. Ali and E.H. Abuo-Egla, 1994. Effect of gibberellic 
acid on broiler chickens performance and some metabolic parameters. Arch. Anim. Nutr., 46: 269-276.

Ahmad, H.A., S.S. Yadalam and D.A.Sr. Roland, 2003. Calcium requirements of bovanes hens. International Journal of Poultry Science 2 (6): 417-420.

Alkhiat, A.A., H. Morsy, E. Shehata and A. Abdellatif, 1981. Veterinary pharmacology and toxicology. Ministry of High Education and Scientific Research Iraq.

Andreson, D.L., R.D. Witkowsky and A.M. Gawienowski, 1982. Effect of gibberellic acid on production characteristics of aged and force molted chickens in cages. Poultry science, 61: 1660-1666.

Armstrong, W.D. and C.W. Carr, 1964. Physiological chemistry laboratory direction. 3 rd. E. Burses publishing Co., Minneopollis, Minnesota, U.S.A.

Aswathanrayana, S.C. and M. Mahadevappa, 1977. Determination of optimum stage of gametocyte application in inducing pollen sterility for production of hybrid rice. Mysore J. Agric. Sci., 25(3): 284-287.

Bell, D.J. and B.M. Freeman, 1971. Physiological and biochemistry of the domestic fowl. Academic Press. London. New york.

Bollengier-Lee, S.P., E.V. Williams and C.C. Whitehead, 1999. Optimal dietary concentration of vitamin $\mathrm{E}$ for alleviating the effect of heat stress on egg production in laying hens. British Poultry Science, vol. 40, no. 1, pp. 102-107.

Dantzer, R. and K.W. Kelly, 1989. Stress and immunity: an integral view of relationships between the brain and immune system. Life Sciences, vol. 44, pp. 1995-2008.

De Fariara, D.E, O.M. Junqueira, P.A. Souza and E.A.I. Titto, 2001. Performance, body temperature and egg quality of laying hens fed vitamins $\mathrm{D}$ and $\mathrm{C}$ under three environmental temperatures," Brasilian Journal of Poultry Science, vol. 3, pp. 4956.

De Man, W., A. De Loof, T. Briers and R. Huybrechts, 1991. Effect of abscisic acid on vitellogenesis in Sareophaga bullata. Entomol Exp Appl 1991; 29: 259-267.

Duncan, D.B., 1955. Multiple range and multiple F. test. Biometric, 11: 1-42.

Eilers, R.I., 1967. Notification of final adoption of an international method and standard solution for hemoglobinometry: Specific for preparation of standard solution. Am. J. Clin. Pathol., 47: 212-214.

El-Afifi, Sh.F. and A.M. Abou Taleb, 2002. Calcium absorption and deposition in old egg-laying Japanese quail as affected by dietary supplemintation with estradiol and cholicalciferol. Egypt. Poultry Science, 22 (III): 855-868.

Elkomy, A.E., A. Samar Elnagar and Azza ElSebai, 2008. Steroidogenic effects of gibberellic acid (GA3) on chicks. Egypt Poult Sci. 27(4): 1239-1255.

El-mofty, M.M. and S.A. Sakr, 1988. Introduction of neoplasms in the Egyptian Toad by gibberellin A3. Oncology, 45: 6164.

El-Sebai Azza, M. Abaza and Samar A. Elnagar, 2003. Physiological effects of "Gibberellic acid (GA3)" on female Japanese quail production and reproduction. Egypt. Poult. Sci. Vol. 23 (IV): 977-992.

Gawienowski, A.M. and D. Chatterijee, 1980. Effect of prostaglandin inhibitor on the uterotrophic response of estradiol and gibberellic acid. Life Sciences, 27: 13931396.

Gawienowski, A.M, S.S. Stadnicki and M. Stacewicz-sapuntzakis, 1977. Synergistic uterotrophic effect of gibberellic acid and estradiol in the immature mouse. Life Sciences, 20: 785-788.

Grunder, A.A, K.G. Hollands and C.P.W. Tsang, 1983. Plasma estrogen, calcium and shell quality in tow strains of white leghorn. Poultry Science, 62: 1294-1296.

Hamdy, A.M.M, N.M. Esa, and A.A. Bakir, 2002. Prediction of of egg production by some body measurments and plasma steroids hormones. Egypt. Poult. Sci., 22: (1) $205-218$.

Ismail, El.I., 2009. Physiological and reproductive studies on laying hens. $\mathrm{Ph}$. D. Thesis, Faculity of Agric., Zagazig. Uni., Zagazig, Egypt.

Khalifa, M.A, M.K Shebaita, G.A.R. Kamar and M.A. Abdou, 1983. Effect of thyroxin, estradiol and ACTH on egg characters and some reproductive organs in Fayoumi. Egypt. J. Anim. Prod., 23 (1-2): 95-107.

Kirunda, D.F., S.E. Scheideler and S.R. McKee, 2001. The efficacy of vitamin E (DL-alpha-tocopheryl acetate) supplementation in hen diets to alleviate egg quality deterioration associated with high temperature exposure. Poult. Sci. 80: 1378-1383.

Madacsi, J.P., F.W. Parrish and J.L.M. Naaughton, 1988. Anim. Feed Science and Technol. 20: 69.

Mahmoud, K.Z, M.M. Beck, S.E. Scheideler, M.F. Forman, K.P. Anderson and S.D. Kachman, 1996. Acute high environmental temperature and calcium-estrogen relationships in the hen. Poultry Science, vol. 75 , no. 12, pp. 1555-1562.

Mashaly, M.M., G.L. Hendricks, M.A. Kalama, A.E. Gehad, A.O. Abbas and P.H. 
Patterson, 2004. Effect of Heat Stress on Production Parameters and Immune Responses of Commercial Laying Hens1. Poultry Science 83: 889-894.

Meltzer, A., 1987. Acclimatization to ambient temperature and its nutritional consequences. In. World's Poult. Sci. J., 43 , pp. 33-44.

Muiruri, H.K. and P.C. Harrison, 1991. Effect of roost temperatureon performance of chickens in hot ambient environments. Poult. Sci. 70: 2253-2258.

Muthul, S., P. Muthuraman, V. Muthuviveganandavel and K. Srikumar, 2011. Acute effect of gibberellic acid on serum enzymes and blood markers in male albino rats. International Journal of Drug Delivery 3: 340-347.

Narvaez-Solarte, W., H.S. Rostagno, P.R. Soares, L.F. Uribe-Velasquez and M.A. Silva, 2006. Nutritional requerment of Calcium in White Laying hens from 46 to 62 wk of age. International Journal of Poultry Science 5 (2): 18 -184.

Niu, Z., F. Liu, Q. Yan and L. Li, 2009. Effect of different levels of selenium on growth performance and immune competence of broilers under heat stress. Archives of Animal Nutrition, 63: 56-65.

NRC, 1994. National Research Council. Nutrient Requirements of Poultry. $9^{\text {th }}$ ed., National Academy of Science, Washington. D.C., USA.

Oladele, S.B., S. Ogundipc, J.O. Ayo, and K.A.N. Esievo, 2001. Effects of season and sex on packed cell volume, haemoglobin and total proteins of indigenous pigeons in Zaria, Northern Nigeria. Veterinarski Arhiv, vol. 71, no. 5, pp. 277-286.

Oladele, S.B, S. Ogundipe, J.O. Ayo and K.A.N. Esievo, 2003. Seasonal and species variations in erythrocyte osmotic fragility of indigeneous poultry species in Zaria, Northern Guinea Savannah zone of Nigeria. Bulletin of Animal Health and Production in Africa, vol. 51, pp. 204-214.

Pearce, J. and H. Johnson, 1986. Failure of oestradiol administration to induce fatty liver haemorrhagic syndrome in the laying hen. British Poultry Science, 27: 41-47.

Pelicia, K., E.A. Garcia, A.B.G. Faitarone, A.P. Silva, D.A. Berto, A.B. Molino and F. Vercese, 2009. Calcium and available phosphorus levels for laying hens in second production cycle. Rev. Bras. Cienc. Avic. 11 (1).

Riley, J.M., 1987. Gibberellic acid for fruit set and seed germination. CRFG Journal, 19: 10-12.

Sahin, N, K. Sahin and O. Küçük, 2001. Effects of vitamin $\mathrm{E}$ and vitamin $\mathrm{A}$ supplementation on performance, thyroid status and serum concentrations of some metabolites and minerals in broilers reared under heat stress $\left(32^{\circ} \mathrm{C}\right)$. Veterinarni Medicina, vol. 46, no. 11-12, pp. 286-292.

Salisbury, F.B. and C.W. Ross, 1992. Plant physiology. Belmont, CA: Wadsworth; p357-407: 531-548.

Schmit, J.M. 1964. Determination of total lipids. These, Lyon, France.

Seetharim, A. and P. Ksuma-Kumari, 1975. Induction of male sterility by gibberellic acid in sunflower. Indian J. Genet. Breed., 35: 136-138.

SPSS program, 1993. Statistical Package for Social Science, SPSS for Windows. Computer Program, version, 5-1.

Winterobe, M.M., 1967. Clinical Hematology; 6th ed. London: Kimpton

Wise, W.A., 1965. Determination of serum albumen. King, Waschr, 43: 273.

Zhou, W.T., M. Fujita, S. Yamamoto, K. Iwasaki, R. Ikawa, H. Oyama and $\mathrm{H}$. Horikawa, 1998. Effects of glucose in drinking water on the changes in whole blood viscosity and plasma osmolality of broiler chickens during high temperature exposure. Poult. Sci. 77: 644-647.

Zulkifli, I., R.T. Doss and M.T. Che Norma, 1999. Acute heat stress effects on physiology and fear related behavior in red jungle fowl and domestic fowl. Canadian Journal of Animal Science, 79: 165-170. 
Table 1. Monthly egg number; egg weight and some egg quality $( \pm \mathrm{SE})$ parameters of laying hens treated with GA3 during winter and summer seasons

\begin{tabular}{|c|c|c|c|c|c|c|}
\hline \multirow[b]{2}{*}{ Items } & \multicolumn{6}{|c|}{ Traits } \\
\hline & $\begin{array}{l}\text { Monthly egg } \\
\text { number (egg) }\end{array}$ & $\begin{array}{l}\text { Egg weight } \\
\text { (g) }\end{array}$ & $\begin{array}{c}\text { Yolk weight } \\
\%\end{array}$ & $\begin{array}{l}\text { Albumen } \\
\text { weight } \%\end{array}$ & $\begin{array}{c}\text { Shell } \\
\text { weight \% }\end{array}$ & $\begin{array}{c}\text { Shell } \\
\text { thickness } \\
(\mathbf{m m})\end{array}$ \\
\hline Seasons & ns & ns & Ns & ns & ns & ns \\
\hline Winter & $20.37 \pm 0.18$ & $62.90 \pm 0.35$ & $23.98 \pm 0.29$ & $63.77 \pm 0.44$ & $12.23 \pm 0.28$ & $0.35 \pm 0.03$ \\
\hline Summer & $20.50 \pm 0.22$ & $63.19 \pm 0.41$ & $23.57 \pm 0.25$ & $64.09 \pm 0.79$ & $12.15 \pm 0.19$ & $0.34 \pm 0.04$ \\
\hline GA3 levels & $* *$ & ns & ns & ns & ns & $* *$ \\
\hline Control & $19.09 \pm 0.27^{\mathrm{b}}$ & $62.34 \pm 0.61$ & $23.35 \pm 0.38$ & $64.66 \pm 0.47$ & $12.05 \pm 0.21$ & $0.34 \pm 0.05^{\mathrm{b}}$ \\
\hline $200 \mu \mathrm{g}$ & $21.15 \pm 0.17^{\mathrm{a}}$ & $63.07 \pm 0.38$ & $24.06 \pm 0.25$ & $64.01 \pm 0.41$ & $11.96 \pm 0.26$ & $0.36 \pm 0.04^{\mathrm{a}}$ \\
\hline $400 \mu \mathrm{g}$ & $21.07 \pm 0.21^{\mathrm{a}}$ & $63.74 \pm 0.37$ & $23.92 \pm 0.34$ & $63.12 \pm 1.20$ & $12.56 \pm 0.36$ & $0.36 \pm 0.03^{\mathrm{a}}$ \\
\hline Interactions & ns & ns & ns & ns & ns & ns \\
\hline Winter x Control & $19.19 \pm 0.36$ & $61.34 \pm 1.01$ & $23.62 \pm 0.63$ & $65.23 \pm 0.57$ & $11.81 \pm 0.26$ & $0.34 \pm 0.04$ \\
\hline Winter x $200 \mu \mathrm{g}$ & $21.05 \pm 0.23$ & $63.97 \pm 0.44$ & $24.41 \pm 0.33$ & $64.14 \pm 0.72$ & $12.16 \pm 0.40$ & $0.35 \pm 0.01$ \\
\hline 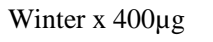 & $20.89 \pm 0.24$ & $63.88 \pm 0.52$ & $23.92 \pm 0.50$ & $62.91 \pm 2.23$ & $12.48 \pm 0.29$ & $0.36 \pm 0.03$ \\
\hline Summer $\mathrm{x}$ control & $19.00 \pm 0.40$ & $62.94 \pm 0.67$ & $23.08 \pm 0.46$ & $64.10 \pm 0.74$ & $12.28 \pm 0.33$ & $0.034 \pm 0.01$ \\
\hline Summer x 200 $\mu \mathrm{g}$ & $21.25 \pm 0.27$ & $62.17 \pm 0.59$ & $23.71 \pm 0.37$ & $63.89 \pm 0.49$ & $11.77 \pm 0.35$ & $0.37 \pm 0.03$ \\
\hline Summer x $400 \mu \mathrm{g}$ & $21.30 \pm 0.34$ & $63.58 \pm 0.53$ & $23.91 \pm 0.49$ & $63.33 \pm 1.07$ & $12.64 \pm 0.69$ & $0.36 \pm 0.02$ \\
\hline
\end{tabular}

a,b, :means in the same column within each item, bearing different superscripts are significantly different $(\mathrm{P} \leq 0.05)$.

$* *=$ highly significant $(\mathrm{P}<0.01)$ and $\mathrm{ns}=$ not significant.

Table 2. Some haematological parameters $( \pm \mathrm{SE})$ of laying hens treated with GA3 during winter and summer seasons

\begin{tabular}{|c|c|c|c|c|c|c|c|}
\hline \multirow[b]{2}{*}{ Items } & \multicolumn{7}{|c|}{ Traits } \\
\hline & $\begin{array}{c}\text { WBCs } \\
\left(\times 10^{3} / \mathrm{ml}\right)\end{array}$ & $\begin{array}{c}\text { RBCs } \\
\left(\times 10^{6} / \mathrm{ml}\right)\end{array}$ & Hb (g/dl) & $\operatorname{PCV}(\%)$ & $\begin{array}{c}\text { Heterocyte } \\
(\%)\end{array}$ & $\begin{array}{c}\text { Lymphocyte } \\
(\%)\end{array}$ & H/L ratio \\
\hline Seasons & $* *$ & $*$ & ns & $*$ & $* *$ & $* *$ & ns \\
\hline Winter & $11.73 \pm 0.29$ & $1.68 \pm 0.04$ & $13.38 \pm 0.28$ & $32.25 \pm 0.60$ & $23.19 \pm 0.59$ & $64.74 \pm 1.19$ & $0.36 \pm 0.010$ \\
\hline Summer & $10.32 \pm 0.28$ & $1.82 \pm 0.05$ & $14.52 \pm 0.28$ & $31.03 \pm 0.80$ & $21.41 \pm 0.53$ & $60.07 \pm 1.21$ & $0.36 \pm 0.009$ \\
\hline GA3 levels & ** & * & ns & * & ns & * & ns \\
\hline Control & $10.05 \pm 0.35^{\mathrm{b}}$ & $1.64 \pm 0.05^{\mathrm{b}}$ & $13.58 \pm 0.48$ & $32.28 \pm 0.91^{\mathrm{a}}$ & $21.39 \pm 0.57$ & $59.11 \pm 1.45^{\mathrm{b}}$ & $0.37 \pm 0.012$ \\
\hline $200 \mu \mathrm{g}$ & $10.97 \pm 0.41^{\mathrm{b}}$ & $1.84 \pm 0.05^{\mathrm{a}}$ & $13.95 \pm 0.39$ & $29.39 \pm 0.98^{\mathrm{b}}$ & $22.50 \pm 0.58$ & $63.33 \pm 1.28^{\mathrm{a}}$ & $0.36 \pm 0.009$ \\
\hline $400 \mu \mathrm{g}$ & $12.04 \pm 0.33^{\mathrm{a}}$ & $1.76 \pm 0.06^{\mathrm{ab}}$ & $14.34 \pm 0.51$ & $33.27 \pm 0.93^{\mathrm{a}}$ & $23.00 \pm 0.91$ & $64.78 \pm 1.47^{\mathrm{a}}$ & $0.36 \pm 0.014$ \\
\hline Interactions & ns & ns & ns & ns & $\mathrm{ns}$ & ns & ns \\
\hline $\begin{array}{l}\text { Winter } \mathrm{x} \\
\text { Control }\end{array}$ & $9.42 \pm 0.45$ & $1.55 \pm 0.06$ & $12.91 \pm 0.68$ & $31.33 \pm 0.39$ & $20.33 \pm 0.86$ & $56.89 \pm 1.06$ & $0.37 \pm 0.013$ \\
\hline $\begin{array}{l}\text { Winter } \mathrm{x} \\
200 \mu \mathrm{g}\end{array}$ & $10.08 \pm 0.35$ & $1.75 \pm 0.07$ & $13.45 \pm 0.51$ & $29.33 \pm 0.48$ & $21.67 \pm 0.84$ & $61.56 \pm 1.21$ & $0.36 \pm 0.015$ \\
\hline $\begin{array}{l}\text { Winter } x \\
400 \mu \mathrm{g}\end{array}$ & $11.43 \pm 0.49$ & $1.74 \pm 0.08$ & $13.80 \pm 0.61$ & $32.45 \pm 0.63$ & $22.22 \pm 1.74$ & $61.71 \pm 1.24$ & $0.35 \pm 0.032$ \\
\hline $\begin{array}{l}\text { Summer x } \\
\text { control }\end{array}$ & $10.68 \pm 0.47$ & $1.73 \pm 0.06$ & $14.25 \pm 0.64$ & $33.23 \pm 0.31$ & $22.44 \pm 1.13$ & $61.33 \pm 1.92$ & $0.36 \pm 0.019$ \\
\hline $\begin{array}{l}\text { Summer x } \\
200 \mu \mathrm{g}\end{array}$ & $11.86 \pm 0.31$ & $1.94 \pm 0.05$ & $14.44 \pm 0.69$ & $29.44 \pm 0.29$ & $23.33 \pm 1.16$ & $65.11 \pm 1.96$ & $0.35 \pm 0.011$ \\
\hline $\begin{array}{l}\text { Summer } x \\
400 \mu \mathrm{g}\end{array}$ & $12.65 \pm 0.42$ & $1.79 \pm 0.10$ & $14.87 \pm 0.59$ & $34.11 \pm 0.35$ & $23.78 \pm 1.85$ & $67.78 \pm 0.83$ & $0.36 \pm 0.022$ \\
\hline
\end{tabular}


Table 3. Some blood components $( \pm \mathrm{SE})$ of laying hens treated with GA3 during winter and summer seasons

\begin{tabular}{|c|c|c|c|c|c|}
\hline \multirow[b]{2}{*}{ Items } & \multicolumn{5}{|c|}{ Traits } \\
\hline & $\begin{array}{l}\text { Total protein } \\
\text { (g/dl) }\end{array}$ & $\begin{array}{l}\text { Albumin } \\
\text { (g/dl) }\end{array}$ & $\begin{array}{l}\text { Globulin } \\
\text { (g/dl) }\end{array}$ & Glucose (mg/dl) & $\begin{array}{l}\text { Total lipids } \\
\text { (mg/dl) }\end{array}$ \\
\hline Seasons & $* *$ & ns & $*$ & $* *$ & $* *$ \\
\hline Winter & $4.65 \pm 0.11$ & $2.36 \pm 0.09$ & $2.29 \pm 0.08$ & $210.23 \pm 5.99$ & $1447.23 \pm 34.99$ \\
\hline Summer & $4.33 \pm 0.08$ & $2.28 \pm 0.06$ & $2.05 \pm 0.05$ & $234.72 \pm 6.65$ & $1304.35 \pm 25.22$ \\
\hline GA3 levels & $* *$ & $* *$ & ns & $\mathrm{ns}$ & $\mathrm{ns}$ \\
\hline Control & $4.24 \pm 0.08^{b}$ & $2.14 \pm 0.05^{\mathrm{b}}$ & $2.10 \pm 0.09$ & $217.55 \pm 7.38$ & $1333.46 \pm 26.36$ \\
\hline $200 \mu \mathrm{g}$ & $4.44 \pm 0.10^{b}$ & $2.24 \pm 0.10^{\mathrm{b}}$ & $2.20 \pm 0.09$ & $219.95 \pm 7.89$ & $1396.89 \pm 46.08$ \\
\hline $400 \mu \mathrm{g}$ & $4.78 \pm 0.13^{\mathrm{a}}$ & $2.57 \pm 0.08^{\mathrm{a}}$ & $2.22 \pm 0.09$ & $229.92 \pm 9.05$ & $13.97 .30 \pm 54.09$ \\
\hline Interactions & ns & $\mathrm{ns}$ & ns & ns & Ns \\
\hline Winter x Control & $4.29 \pm 0.11$ & $2.13 \pm 0.09$ & $2.16 \pm 0.13$ & $206.59 \pm 8.60$ & $1392.72 \pm 17.53$ \\
\hline Winter x $200 \mu \mathrm{g}$ & $4.67 \pm 0.10$ & $2.29 \pm 0.17$ & $2.38 \pm 0.14$ & $206.42 \pm 10.92$ & $1476.31 \pm 70.36$ \\
\hline Winter $\mathrm{x} 400 \mu \mathrm{g}$ & $4.98 \pm 0.20$ & $2.65 \pm 0.14$ & $2.33 \pm 0.16$ & $217.69 \pm 12.78$ & $1472.67 \pm 80.52$ \\
\hline Summer $\mathrm{x}$ control & $4.20 \pm 0.12$ & $2.15 \pm 0.04$ & $2.05 \pm 0.12$ & $228.51 \pm 10.55$ & $1274.19 \pm 32.60$ \\
\hline Summer x $200 \mu \mathrm{g}$ & $4.21 \pm 0.09$ & $2.19 \pm 0.09$ & $2.02 \pm 0.04$ & $233.49 \pm 8.34$ & $1317.46 \pm 38.05$ \\
\hline Summer x $400 \mu \mathrm{g}$ & $4.58 \pm 0.13$ & $2.48 \pm 0.08$ & $2.10 \pm 0.08$ & $242.15 \pm 11.42$ & $1321.39 \pm 61.82$ \\
\hline
\end{tabular}

Table 4. Fertility, hatchability and chick weight percenteges $( \pm \mathrm{SE})$ of laying hens treated with GA3 during winter and summer seasons

\begin{tabular}{|c|c|c|c|c|c|}
\hline \multirow[b]{2}{*}{ Items } & \multicolumn{5}{|c|}{ Traits } \\
\hline & Fertility \% & $\begin{array}{c}\text { Hatchability } \\
\text { of total egg set } \\
\%\end{array}$ & $\begin{array}{l}\text { Hatchability of } \\
\text { fertile eggs \% }\end{array}$ & $\begin{array}{c}\text { Chick } \\
\text { weight }(g)\end{array}$ & $\begin{array}{c}\text { Chick weight } \\
\%\end{array}$ \\
\hline Seasons & ns & ns & ns & $*$ & $*$ \\
\hline Winter & $78.89 \pm 4.30$ & $58.89 \pm 5.22$ & $74.65 \pm 5.20$ & $38.54 \pm 0.29$ & $65.67 \pm 0.38$ \\
\hline Summer & $75.56 \pm 4.56$ & $55.56 \pm 5.27$ & $73.53 \pm 5.39$ & $37.71 \pm 0.28$ & $64.70 \pm 0.37$ \\
\hline GA3 levels & $*$ & ns & ns & ns & ns \\
\hline Control & $66.67 \pm 6.14^{b}$ & $50.00 \pm 6.51$ & $75.00 \pm 6.93$ & $37.98 \pm 0.29$ & $64.97 \pm 0.49$ \\
\hline $200 \mu \mathrm{g}$ & $78.33 \pm 5.36^{\mathrm{ab}}$ & $56.67 \pm 6.45$ & $72.34 \pm 6.60$ & $37.98 \pm 0.38$ & $64.75 \pm 0.45$ \\
\hline $400 \mu \mathrm{g}$ & $86.67 \pm 4.43^{\mathrm{a}}$ & $65.60 \pm 6.21$ & $75.00 \pm 6.06$ & $38.39 \pm 0.38$ & $65.77 \pm 0.44$ \\
\hline Interactions & $\mathrm{ns}$ & $\mathrm{ns}$ & $\mathrm{ns}$ & ns & $\mathrm{ns}$ \\
\hline Winter x Control & $70.00 \pm 8.51$ & $53.33 \pm 8.69$ & $76.19 \pm 9.51$ & $38.30 \pm 0.43$ & $65.51 \pm 0.69$ \\
\hline Winter x $200 \mu \mathrm{g}$ & $80.00 \pm 7.42$ & $60.00 \pm 9.09$ & $75.00 \pm 9.01$ & $38.66 \pm 0.48$ & $65.44 \pm 0.68$ \\
\hline 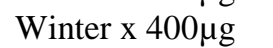 & $86.67 \pm 6.31$ & $63.33 \pm 8.94$ & $73.08 \pm 8.86$ & $38.64 \pm 0.57$ & $65.49 \pm 0.65$ \\
\hline Summer $\mathrm{x}$ control & $63.33 \pm 8.94$ & $46.67 \pm 9.26$ & $73.68 \pm 10.40$ & $37.62 \pm 0.35$ & $64.34 \pm 0.69$ \\
\hline Summer x $200 \mu \mathrm{g}$ & $76.67 \pm 7.85$ & $53.33 \pm 9.25$ & $69.57 \pm 10.25$ & $37.22 \pm 0.57$ & $63.92 \pm 0.49$ \\
\hline Summer x $400 \mu \mathrm{g}$ & $86.67 \pm 6.31$ & $66.67 \pm 8.75$ & $76.92 \pm 8.13$ & $38.16 \pm 0.51$ & $65.57 \pm 0.64$ \\
\hline
\end{tabular}


تأثير حمض الجبريليك على بعض القياسـات الفسيولوجية والتناسلية والفقس للاجاج البياض أثناء موسسى الثتاء و الصيف التير

\author{
علي عبدالرازق سيد أحمد عسكر، إسماعيل السيد إسماعيل \\ قسم الدواجن، كلية الزراعة، جامعة الزقازيق، الزقازيق، مصر
}

اجريت التجربة للدراسة التأثير الهرمونى لحمض الجبريليك على بعض الصفات الفسيولوجية و التناسلية والاداء التفريخى للاجداج

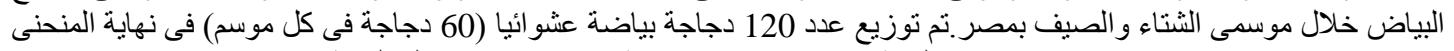

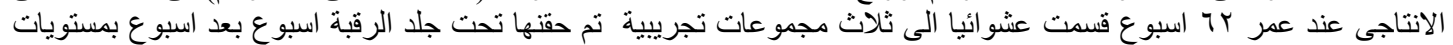

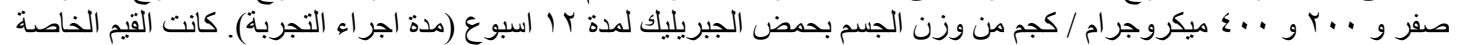

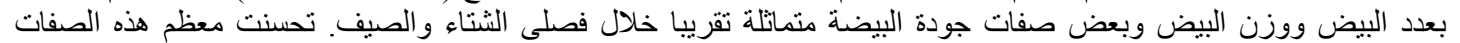

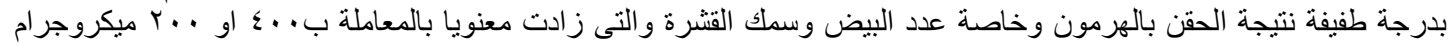

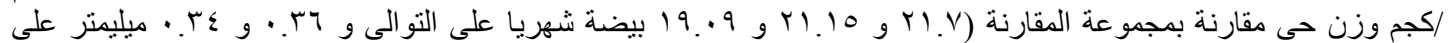

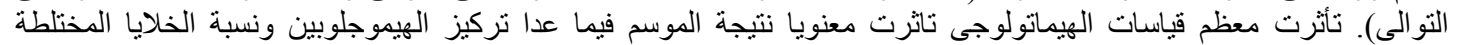

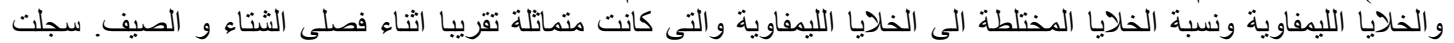

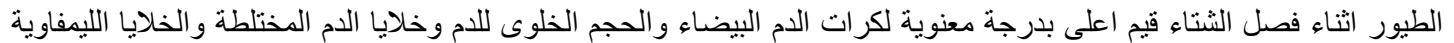

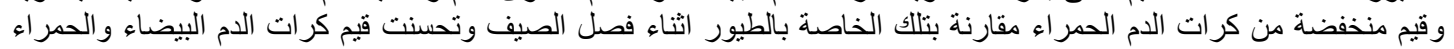

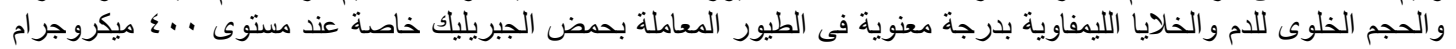

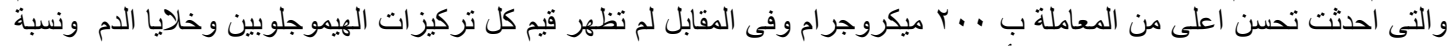

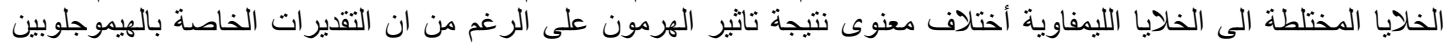

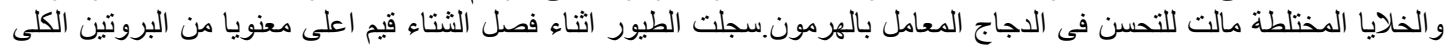

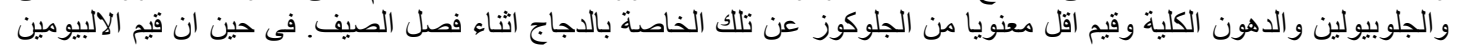

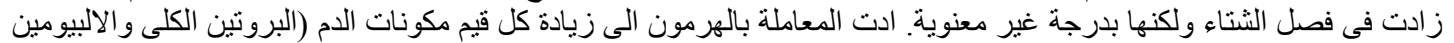

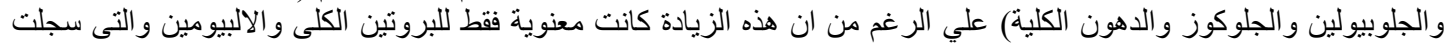

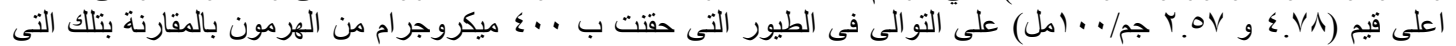

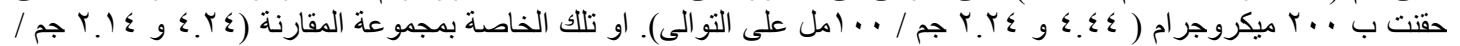

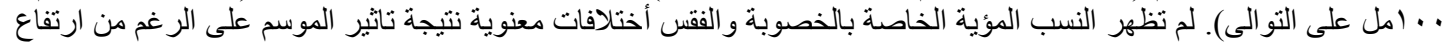

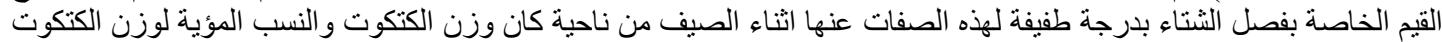

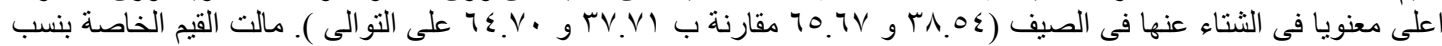

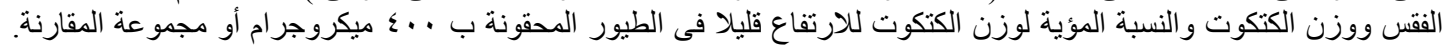

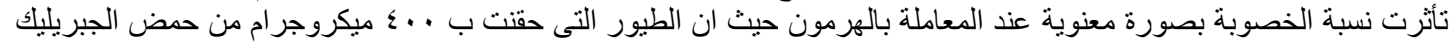
سجلت اعلى قيمة (

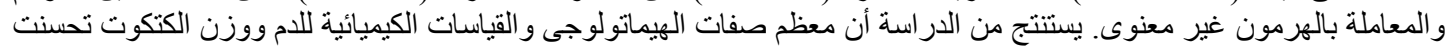

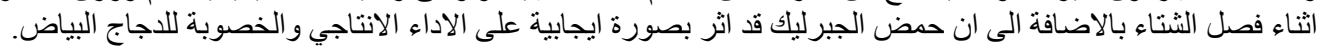

